\title{
Faces of women through historical reality and ecology of woman's nature awareness
}

\author{
Štefanija Jaksetič Dujc \\ doctoral student of the University of Ljubljana
}

\section{Abstract}

A woman as a human being, as a partner to a man, and a woman as a mother and a parent carries within herself all the historical reality of these complex roles. In every woman as a descendant of her species, there is a wealth of life experience of her ancestors, and especially her female predecessor.

The desire and the need for physical and mental health of an individual, society and nature we ever more realize how important the integration and combining advanced skills and knowledge are. The field of ecology and the study of relations between animate and inanimate nature is finally transmitted to the ecology of human mind and is also associated with human relations and visions as well as human integrity and the relation to both animate and inanimate nature.

In this context, and based on the spread of new knowledge about an individual's psyche and the importance of his or her primal experience of being attached, a woman as a parent, a mother and the first guardian, is in the focus of modern research. Due to the complexity and indispensability of the role of women as partners, mothers and bearers of historical realities and habits, only the in-depth and comprehensive research in the field of modern family relational and system psychotherapy, opened the possibility of a dignified exploration of the role of a woman as an essential factor while the dependent particle within a family's dynamics.

Creating an intimate, even sacred or ecological space and time is where and when the re-discovery of the deepest natural needs and natural feelings of an individual in his or her most vulnerable and intimate period may, and must take place. This period is the period of a newborn and the period of intimate partner relationship where an individual creates and maintains his or her 
human vulnerability and acceptance. An intimate and an equal partnership offers an opportunity to raise awareness of the historical reality weight, that both partners unconsciously bring in their current relationship through their past relations experience, which is a basis for a naturally spontaneous maternal relationship.

Keywords: woman, partner, parent, relationships, ecology, intimacy

\section{Introduction}

Role of a woman in the natural system of a family

The woman, as a human and as an individual, is an integral part of the family in terms of relational, systemic and intergenerational system, as demonstrated by modern psychotherapeutic science (Bowen \& Kerr 1988; Gostečnik 1998, 2004, 2011). Among the first researchers of family there was Bowen who argued in his longitudinal studies from 1940 onwards that a family system is a natural system and not the system that was invented by a man (Bowen \& Kerr 1988). A family system contains a complex dynamics that maintains the system, just like all natural systems. He also added that a human community like a family differs from other natural systems due to human awareness. Besides the awareness there is also a constant balancing or adjusting of rationality and emotions (Bowen \& Kerr 1988). The concept of the family as the natural system challenges the thinking that the world revolves around an individual, even though, historically looking, the belief that all the constellations revolve around the earth was also wrong for thousands of years. In fact, according to Bowen, it is the individual's behaviour, the dynamics of relationships and interplay of numerous unconscious, historical, developmental and emotional dynamics of family and community and plays a part of the natural dynamics of the family as the natural system. To understand, and in particular, to adopt this truth, Bowen claimed that it takes a lot of mental and emotional effort. Namely, it is necessary to stand out from the established way of thinking and try to understand each individual. We must understand every one as an individual, via the empathic understanding as an individual and also as a part of the family community from which he or she derives. (Bowen \& Kerr 1988). 
Natural role of a woman in the system of family relationships

The article is an attempt to present and understand a woman from the perspective of both her individuality and from the point of view of her many roles. At the same time, this is an attempt to understand a woman as a part of family community from which she derives. According to Bowen (Bowen 1978; Bowen \& Kerr 1988 ) and the researchers of Bowen's theory of family community (Skowron \& Friedlander 1998; Skowron \& Schmitt 2003) the individual, the woman is realized through the development of her own personal and interpersonal resources and in coordination with the family, its dynamics and relational systemic family laws (differentiation of self). Furthermore, it is necessary to see a woman as a developmental being who is realized as a human with all the historical and human realities first in the primary family as a daughter, but later on, based on these features, she realises herself in her own family or community and its dynamics. This aspect of inter-culturality established by Bowen (Bowen 1978; Bowen \& Kerr 1988) is now being developed and elaborated on by the researchers like McGoldrick, Lisa Platt and others (McGoldrick 1995 2011; Platt 2008). Next, the woman is realized as an equal member of the community and also as being a partner herself. Her partner who is also carrying intergenerational stories from his nuclear family and his role as a man introduces his personal dynamism and emotion into the dynamics of the family, all on the basis of his own experience and the experience of his nuclear family, which is also important to be recognized. Basic emotional engines of an individual and, consequently, his family, need to be recognised either individually or mutually so that they need not be repeated according to McGoldrick (McGoldrick \& Gerson). However, in this article we will be focused only on the female perspective, with the assumption that both a man and a woman are equivalent in this relationship. Thus, in this paper we remain on the presentation of the role of a women as a teacher and a parent and en educator of descendants who maintains and develops primarily a relational part of the family community, as represented by Christopher West in his work entitled The good news about sex and marriage: „... a woman is formed in relationships and is created for relationships" (West 2012). Therefore, we derive from the perspective that a woman as an individual has a specific role in the family as a natural system that includes all the dynamics of nature that preserves the community.

Nature of a woman and her primary roles

By her nature, a woman tends to become a parent. At the same time she also becomes a primary caretaker for her children. Since this role kept the family 
alive throughout millenniums women were mainly or solely associated with this role. Although this role presents a natural asset it is also the most vulnerable within the human community. Through this role a woman is most thoroughly connected with nature and natural processes as well as with her family and family relations. And today, the exploration and the search for „primary attachment” and how individuals are characterised with primary relationships, researchers are discovering natural role of women as parents and at the same time women as caretakers. It could be said that this aspect opened one of the otherwise vulnerable and not yet deeply understood roles of women. At the same time contemplation and research in this direction is one of the liberating truths about women. Christopher West points out that: „Motherhood that serves the preservation of family fundamentally marks women's relationships" (West 2011).

With her role of primary caretaker a woman reaches into the nucleus of family homeostasis

To put it in a nutshell, women, with their respective roles of parents, primary caretakers, intervene in the core of the family homeostasis, hierarchy and all the other well-established family dynamics. In this procedure, she is selfcontained, and must at the same time stay very open and is therefore extremely vulnerable. She remains torn between taking care of a completely dependent newborn and for maintaining contact and relationship with other family members. The role that initially completely takes her over, physically and mentally actually deprives her having contact with other family members to the extent as before. Until then, the established care and dedication, which she shared with other family members before the arrival of a new member now, requires changes. Modern psychotherapeutic science is wary regarding that period in the life of individuals and families. The attention is due to the trauma resulting from this period. The family is always changing. At the same time a distress and anxiety is both in individuals and, consequently, in a family community. According to Bowen anxiety is a basic response to any changes in the lives of individuals and families. Furthermore, there are no normal and abnormal families, but there are only more or less appropriate ways of identifying and managing anxiety (Bowen 1978; Bowen \& Kerr 1988). Remaining again at the role of women as individuals and at the same time parts of the family. Family dynamics, which is a live, active and basic system in which the individual is formed as a relational being, is also sensitive to the vulnerability of each individual in it. And the vulnerability of mothers makes all other family members vulnerable too. 
Anxiety as a response to relational changes

The perspective for controlling vulnerabilities and consequently the occurrence of anxiety in women is a conscious partnership which receives and evaluates changes and recognizes anxiety (Bowen 1978; Bowen \& Kerr 1988). Only a partnership where awareness is high can assign a woman and make room for her and, consequently, for a new member and all the new things he brings into family. Conscious feelings of anxiety can be transformed, says Bowen, therefore, there are potentials that by sharing feelings and processing them new views are created and new conditions and new meaningful adaptations to life of the individual and the entire family are enabled. Unrecognized, unuttered and unprocessed anxiety finds expression in a variety of deviations from both the individual and the family. This derogation may be in the form of triangulation or resorting to emotional triangles outside the family, or in the triangular problem-solving in the family or at the intergenerational level: parent - child; parent - grandparent, etc. Anxiety can be released through focusing into one of the children (or more children). Or it can be focused on the partner who resorts to disease unknowingly. There can also occur an emotional disconnection, distancing or emotional escape and thereby emotional disintegration of the family emotional unit or family. (Bowen 1978; Bowen \& Kerr 1988)

\section{Woman as a parent and a primary caretaker}

New life, as we can see, brings novelties: new conditions and new opportunities, and at the same time new demands. Consequently the development of the family unit is burdened. Family reacts, as previously said, with anxiety. Anxiety can otherwise occur in individuals but, in reality, the entire family is burdened. Anxiety is in fact released through relationships: with your partner, through the relationship with the child, through triangulation or through an emotional escape, as we mentioned above. And if we remain with a woman, who is according to these developments a carrier and is deeply organically and psychologically involved in the partnership and family relations, we can talk about a key commitment and at the same time the key threat. That means that a woman as a mother and as a caretaker remains alone with her primary and relational roles. This presents a loss to the entire family unit.

\section{Family co-operation}

Conscious and comprehensive cooperation by the partner and the whole family unit brings an exceptional life and relational significance to a woman and, at the same time, to the family unit. As a parent and caretaker a woman can receive new 
insights about her own role and the decision on the role of the caretaker, while at the same time she is dependent on the emotional acceptance and understanding of her partner and the entire family. A woman can and often must be the first one to take permanent decisions regarding the responsibility for a new life and its progress, but at the same time, she is closely linked with her partner and her family, therefore her emotional decisions mark all the relationships within the family. And when a woman accepts an offer of nature her conscious emotional relationship with her partner and her family is essential, since her natural endowment and the ability to be a mother overtake her in all their requirements. By accepting the role of a parent she accepts the natural process of human development, a development of a child that she cannot fully have under control. At the same time she cannot control the emotional potential. She is also emotionally and rationally committed to her partnership and family relations. Thus, only in a conscious relational collaboration with the partner and with the entire family she can fully comprehend, can be co-responsible and willing to create a safe space to accept new life. She has the choice to refuse her primary role of a parent, but also in this case her decision is characterized by a natural processes, which exceeds her and her decision in natural consequences. Even the refusal of new life brings a process into the natural course of the woman's life that is beyond her control. Consequently, this brings a change in the relational sense, and awareness should be raised.

\section{Research on the concept of women throughout history}

\section{Research on women and their roles}

New scientific knowledge from different disciplines, and especially the contemporary needs and desires for physical and mental health of the individual, society and nature, are in search of a more comprehensive view of the world and an individual in it. A woman is especially forced in this change and with her different roles she is either directly or indirectly in the center of various modern research in different disciplines (Lamovec 1984). Market research and, indirectly, the politics and the economics nowadays reach in the area of family, mostly women and children, at the expense of the multiplication of the capital, after centuries of neglect. Unfortunately, too often the encroachment on the area of family and its needs only happens from the point of view of the creation of new needs or in terms of consumption. The needs that might arise from the integrity of the role of women and families, and which would be in line with the role of women as overall personalities, have little or no space. They are only interested in the result of a particular product, a particular problem or a specific method and technique. 
In fact, it looks as if a woman should devote herself every day to one piece of her role or one role only (Lamovec 1984). In short, a woman is also in modern times constantly exposed, directly or indirectly, to research and opinions that are displayed partially or are torn from the context of women's roles. The woman is unprotected and, as such, in fact subjected to all kinds of abuse.

Perspective of more complex modern researches of family and women as primary caretakers

Women actually carry in themselves an intertwinement of various complex roles that touch upon various aspects of an individual's life, and, consequently, the entire family. Thus, her relations are complex and interwoven as well and they include relationships at all levels of social life. In modern times, the assumption and the theory of the so-called models of attachment is very notable (Bowlby, Ainsworth 1966). Research findings reach deep in the field of a woman and one of her primary roles, namely, the role of caretaker. The newborn's attachment to his/her primary caretaker in terms of psychosomatic effects and responses, and the possibility of lifetime consequences thereof, is the basic research finding regarding attachment (Bowlby, Ainsworth 1966). Primal impressions relived by an individual when being a baby on the physical and psychological intimate contact (connection) with the primary custodian are in fact later arisen in the adult individual, when conditions very similar to the experience of the deepest intimacy are created (Bowlby, Ainsworth 1966; Gostečnik 2004 and 2011; Erzar \& Kompan Erzar 2012). The realization that the individual is firstly and foremostly loyal and belongs to that specific type of attachment, obtained in a relational contacts in early childhood, has even pushed out the Freudian instinctive model as the primary life principle of a man (Gostečnik 1998, 2004; Erzar 2008). And in this context it is essential to evaluate a women in her entirety and to help her in raising the awareness of her real and complex role. In light of the role of the creator of primal attachment to an individual who she keeps and re-creates in her most intimate experience, a woman is truly the most powerful and at the same time the most vulnerable family member and a part of its dynamics.

\section{Processes of raising awareness of the role of a woman as an ecologic intervention}

The possibility of change in the direction of recognizing the real nature of a woman and all the roles deriving from her

Anyhow, the scientific view can be an important introduction to the process of raising the importance of a woman in many of her fundamental roles. The 
study of a woman as a human being and as an individual, as well as a constituent part of a family which is relationally, systemically and intergenerationaly designed and works as such is a complex activity. But only in the context of this complex activity a woman can be seen like part of the family and at the same time as marked by her primary family history and dynamics and the family she helps to create (Bowen 1978; Bowen \& Kerr 1988). The study of a woman as an individual and also as a co-creator of the family is complex. As a family with their own rules cannot be identified from the perspective of an individual, similarly as a cell cannot be seen without the organism (Kerr \& Bowen 1988) so a woman cannot be seen as an individual. However, we can see her status as an individual from different perspectives. Namely, in terms of her fundamental emotions and relationships, as envisaged in the concept of relational partner and family therapy (Gostečnik 2004, 2011). This is a complex therapy, and includes the latest findings of systemic family therapy, relational theory and the theory of self. It is based on the recognition of the fundamental feelings and their processing (M. Cvetek 2013). It can be viewed from the perspective of Bowen's six natural concepts: through the recognition of emotional independence from the close family or the differentiation of self, through triangulation dynamics in the family, through emotional processes in family dynamics, through the projection processes in the family, through the transfer of intergenerational emotional dynamics in the family, through positions of siblings in the family, and through two additional Bowen's concepts, namely, emotional separation and social emotional process (Kerr \& Bowen 1988).

\section{A woman as a transporter of emotional history}

Modern science nowadays is capable of confirming with the electronic imaging of the brain (Siegel 2014) and total body screening (Numenmaa 2014) that a man is much more than a mere rational creature in his essence. Human activity and life therefore direct emotions. And precisely in this area, a woman as a bearer of primary relationships (Bowlby, Ainsworth 1966) can be competent and can obtain value. Millenniums of deliberate denial and non-compliance with emotion (Lamovec 1989) were broken with the modern knowledge of the importance of the deepest feelings and came on the field of psychotherapy through the modern systemic and relational assumptions. Relational partnership and family therapy, which is based on the so-called core affects and detection, raising awareness and processing of emotions addresses the individuals, families in their basic emotional complications (Gostečnik 2004, 2011; M. Cvetek 2013) with the aim of assuming power over them. 
Directing the family relation and partnership psychotherapy and Bowen's family theory

Relational family and partner therapy is focused on tracking and tracing fundamental feelings. Raising awareness of fundamental feelings in the process of therapy leads to the feeling being awared of and placed in space and time. The objective of the so-called emotions processing is for the feelings to become manageable or that the individual has access to them and he guides them, not vice versa. Therapeutic tracking and changing the view of the deepest intimate emotions and feelings of individuals and families extends to intergenerational feelings. Modern psychological and psychotherapeutic knowledge discover or confirm intergenerational emotional connection both in a family unit, as well as with the individual. Namely, it can be found in every family unit through awareness of intergenerational emotional connections that repeat through generations in the same family (Kerr \& Bowen 1988).

\section{Creating an intimate, ecological space for the development of an individual}

What does it mean to create an intimate, sacred and ecological space? This is when and where the deepest natural needs and natural feelings of the individual in his most vulnerable and intimate period may and should occur and be re-discovered. The efforts of the relational partner and family therapy is precisely to create a secure atmosphere in which the individual can relive his or her specific emotional reality and, based on his or her own experience, can use it in personal relationships (Gostečnik 2004, 2011). However, this is also the period of infancy and the period of intimate partner relationship where an individual establishes and maintains his or her human vulnerability and acceptance. In an intimate and equal partnership an opportunity is provided to the maternal relationship so that it can be left to its natural spontaneity by raising awareness of the weight of historical facts which are brought by the partners unconsciously in their relationship over their past experiences in relationships.

Ecology of research of the role of a woman through a safe discovery of the truth about her past

A woman, as a human, as a partner of a man, as a mother and a parent, carries within herself all the historical reality of these complex roles. And in every woman who is a descendant of her kind a wealth of life experience of her ancestors, especially her female predecessors is hidden. Relations which were until recently a mystery are today an area that has been intensively researched. 
And the vulnerability of women as well as vulnerability of the discovery of her historical experience and the vulnerable area of family relationships calls for an ethical, cultural and dignified approach, to research and raise awareness of deepest natural truth about emotional integration of individuals and families (Bowen 1978; Bowen \& Kerr 1988).

\section{Conclusion}

I would like to present different thoughts by men, or better, by a man (Evert 2009; West 2012) who wants to come closer to a woman and her vulnerability. According to Bowen and relational theory, opening up old, ancient wounds is a necessity, because only through discovering our vulnerabilities it is possible to supply and heal old wounds and not giving rise to the new ones. „Understanding, support and backing the dignity of women is the mission of every man ... and it seems to me that women often have difficulties accepting the gift of their womanhood because of the wounds which were caused by men by not respecting them enough. The world that depicts women as an object for male pleasure is the world that forces women into a defensive posture." (Evert 2009; West 2012) God created the woman's body to reveal its identity and mission. In the body of every woman there is a sign engraved, saying that she is competent to love and to be loved and created for relationships. „When you study the way God designed your body - and your wishes - you can know who you are as a woman, how you are supposed to live, and who created you" (Evert 2009; West 2012).

\section{References}

Bowen, Murray \& Michael E.Kerr. Family Evaluation. The Family Center Georgetown University Hospital, USA: W.W.Norton \& Company, 1988.

Bowen, Murray. La Differanciation du soi. Pariz: ESS, 1984.

Bowlby, John. Attachment and loss. New York: Basic Books, 1969-1980.

Bowlby, John; Ainsworth, Salter D. Mary; Maternal care and mental health. New York, Schocken Books, 1966.

Buber, Martin. Dialoški princip. Translated by Janez Zupet. Društvo 2000, 1999.

Cvetek, Mateja. Čustveno procesiranje in spodbujanje razvoja čustvenega procesiranja v relacijski zakonski in relacijski družinski terapiji. Doktorska disertacija. Ljubljana, 2013.

Cvetek, Mateja. „Integracija Greenspanove teorije funkcionalnega čustvenega razvoja ter relacijske zakonske in družinske terapije - prikaz primera." Edited by $4-5$ Robert Cvetek. In: Zbornik prvega kongresa zakonskih in družinskih terapevtov Slovenije: Zakonska in 
družinska terapija v naslednjem desetletju. Ljubljana: Združenje zakonskih in družinskih terapevtov Slovenije, 30.januar 2010.

Cvetek, Robert. Bolečina preteklosti: Travma, medosebni odnosi, družina, terapija. Edited by Andrej Arko. Društvo Mohorjeva družba in Celjska Mohorjeva družba, 2009.

Cvetek, Robert. Raziskujmo medosebne odnose: priročnik za izvedbo kvantitativne empirične raziskave, (Priročniki TEOF,22). Ljubljana, Slovenija: Teološka fakulteta, 2013.

Erzar, Tomaž. Duševne motnje: Psihopatologija v zakonski in družinski terapiji. Celje, Slo: Celjska Mohorjeva družba; Brat Frančišek, 2007, Maribor, 2007.

Erzar, Tomaž, and Lia Katarina Kompan Erzar. Teorija navezanosti. Celje: Mohorjeva družba, 2013.

Evert. Jason. Teologija telesa zanjo in zanj. Ascension Press 2009: za slovensko izdajo Družina d.o.o, 2011, Ljubljana, 2011

Franz, Marie Luiz. Puer Aeternus. Edited by Riko Rižman in Roman Kos. Translated by Marjan Mlekuž \& Marjeta Kušar. Ljubljana, Slo: ME TA Produkcija, Riharjeva 13, Ljubljana, 1988, 1970.

Gerjolj, Stanko. Živeti, dalati, ljubiti: Pedagoška in psihološka interpretetacija bibličnih pripovedi: Prva Mojzesova knjiga, Druga Mojzesova knjiga, Tobitova knjiga. Vol. 376 str. Celjska Mohorjeva družba, Družtvo Mohorjeva družba, 2009.

Gostečnik, Christian. Človek v začaranem krogu. Ljubljana: Brat Frančišek in Frančiškanski družinski center, 1997.

Gostečnik, Christian. Inovativna relacijska družinska terapija. Ljubljana: Brat Frančišek, Frančiškanski družinski inštitut, Teološka fakulteta UL, 2011.

Gostečnik, Christian. Neprodirna skrivnost intime. Ljubljana: Brat Franšišek in Frančiškanski družinski inštitut, 2010.

Gostečnik, Christian. Relacijska paradigma in travma. Ljubljana: Brat Frančišek in Frančiškanski družinski inštitut, 2008.

Gostečnik, Christian. Relacijska zakonska terapija. Ljubljana: Brat Frančišek in Frančiškanski družinski inštitut, 2007.

Gostečnik, Christian. Sistemske teorije in praksa. Ljubljana: Brat Frančišek in Frančiškanski družinski inštitut, 2010.

Gostečnik, Christian. Srečal sem svojo družino. Ljubljana: Brat Frančišek in Frančiškanski družinski center, 1999.

Gostečnik, Christian. Srečal sem svojo družino II. Ljubljana: Brat Frančišek in Frančiškanski družinski inštitut, 2003.

Gostečnik, Christian. Struktura in dinamika osebnosti "grešnega kozla". Ljubljana: Brat Frančišek in Frančiškanski družinski inštitut,1998.

Jung, Carl G., Franz, Handerson, Jacobi, Jatie. Človek in njegovi simboli. Ljubljana: Mladinska knjiga, Ljubljana, 2003.

Kompan, E. Katarina. Rahločutnost do otrok. Ljubljana: Brat Frančišek in Frančiškanski družinski inštitut, 2009. 
Lamovec, Tanja. Emocije. Ljubljana, Filozofka fakulteta, 1984.

Lamovec, Tanja. Psihodiagnostika osebnosti. Ljubljana : Filozofska fakulteta, 1994.

Lamovec, Tanja. Samo zadovoljna mati je lahko dovolj dobra mati. Ljubljana. Fakulteta za socialno delo, 1998. http://www.dlib.si/?URN=URN:NBN:SI:DOC-W55G3OCY. (19.8.2014).

Lamovec, Tanja. Emocije in obrambni mehanizmi, Zavod SR Slovenije za produktivnost dela, Center za psihodiagnostična sredstva, 1989.

Lamovec, Tanja. Emocije. Ljubljana: Filozofska fakulteta, 1991.

McGoldrick, Monica. The Genogram Journey; Reconnecting with Your Family. New York. Copyright by Monica McGoldrick, 2011.

McGoldrick, Monica. You can go home again. USA. Copyright by Monica McGoldrick, 1995.

Miller, Alice. Drama je biti otrok. Ljubljana: Založba Tangram, 1993.

Miller, Alice. Upor telesa, Telo terja resnico. Ljubljana: Založba Tangram, 2005.

Nummenmaa, Lauri. Bodily maps of emotions. Contributed by Riitta Hari, November 27, 2013

(sent for review June 11, 2013) 646-651, doi: 10.1073/pnas.1321664111. Pridobljeno (4.12.2014).

Platt, Lisa. „Family Genogram Interview, Reliability and Validity of a New Interview Protocol”. The Famiy Journal N. 21 (Sage Journals). Januar 2013: 35- 45. (1.7.2013).

Puhar, Alenka. Prvotno besedilo življenja. Zagreb: Globus, 1982.

Repič, Tanja. Nemi kriki spolne zlorabe in novo upanje. Edited by Mohorjeva družba. Celje, Slo: Celjska Mohorjeva družba, 2008.

Skowron, Elizabeth and Friedlander, Myrna L. „The Differentation of Self Inventory.” Journal of Counseling Psychology, 1998, Vol. 45, No. 3, 235-246 (American Psychology Association, Inc. 0022-0167/98), 1998. (15.8.2013).

Skowron, Elizabeth A. and Schmitt A. Tomas. Reliability and validity of a new DSI fusion with others subscale. Journal of Marital and Family Therapy - Vol. 29 - Issue 2 - 2003 - pp. 209-222. (15.8.2013).

Spielberger, Charls. Stres in tesnoba. Murska Sobota: Pomurska Založba, 1985.

West, Christopher. Dobra novice o spolnosti in zakonu. Ljubljana: Založba Družina, 2012. 
